\title{
PROJECT MANAGEMENT MATURITY: AN ASSESSMENT OF MATURITY FOR DEVELOPING PILOT PLANTS
}

\author{
H.K. Mittermaier ${ }^{1}$ and H. Steyn \\ Graduate School of Technology Management \\ University of Pretoria, South Africa \\ herman.steyn@up.ac.za
}

\begin{abstract}
Despite the current economic climate, the South African mining and engineering industry is experiencing a very promising future, with a large number of capital projects in the offing. It is inevitable that pilot plant development will form part of this future as a risk mitigation technique. This study found that, even though the terms 'pilot plant' and 'project management maturity' are familiar within the industry, no link between these two could be found in the literature. A number of maturity models exist; and one developed by PMSolutions was selected to perform an assessment of the current level of project management maturity within the South African mining and engineering industry pertaining to the development of pilot plants. The Delphi technique was used to determine the views of experts in the South African mining, mineral processing, petrochemical, nuclear, and mechanical sectors regarding this maturity. A significant difference was observed between the current level of maturity and the required level of maturity in all but one of the nine knowledge areas defined by the Project Management Institute. The two knowledge areas of project time and risk management showed significant differences between current and required maturity levels, and were identified as key areas for improvement.
\end{abstract}

\section{OPSOMMING}

Ten spyte van die huidige ekonomiese klimaat ondervind die Suid-Afrikaanse mynbou- en ingenieursbedryf ' $n$ baie bemoedigende toekoms, met 'n groot aantal kapitaalprojekte in die vooruitsig. Ten einde risiko's te verlaag, sal die ontwikkeling van loodsaanlegte noodwendig deel van hierdie toekoms uitmaak. Daar is gevind dat, alhoewel die terme 'loodsaanleg' en 'projekbestuur volwassenheid' in die nywerheid bekend is, geen skakeling van hierdie twee terme in die literatuur opgespoor kon word nie. 'n Aantal volwassenheid modelle bestaan; en een wat deur PMSolutions ontwikkel is, is gekies om die huidige vlak van projekbestuur volwassenheid in die Suid-Afrikaanse mynbou- en ingenieursbedryf ten opsigte van loodsaanlegte te bepaal. Die Delphi tegniek is gebruik om die sienings van deskundiges in die Suid-Afrikaanse mynbou-, mineraalprosessering-, petrochemiese-, kern-, en meganiese sektore oor die genoemde volwassenheid te bepaal. ' $\mathrm{n}$ Beduidende verskil is waargeneem tussen die huidige en die gewensde vlakke van volwassenheid in agt van die nege kennisareas soos gedefinieer deur die Amerikaanse Project Management Institute. Beduidende verskille tussen huidige en gewensde vlakke van volwassenheid is veral in die twee kennisareas projek tydbestuur en projek risikobestuur gevind, en dui op areas vir verbetering.

\footnotetext{
${ }^{1}$ The author was enrolled for an M Eng (Project Management) in the Graduate School of Technology Management (GSTM), University of Pretoria.
} 


\section{INTRODUCTION}

The engineering and mining industry in South Africa and sub-Saharan Africa has been very active over the past few decades. The abundance of mineral resources has provided a streaming source of income, as well as economic development in historically impoverished communities. Skill and technology development is also affected immensely, resulting in African countries engaging competitively in local and foreign markets previously dominated by overseas players.

\subsection{Industry and role players}

The presence of mineral resources like gold, diamonds, platinum, coal, and many others in South Africa and neighbouring countries, has led to the successful establishment of businesses operating in these areas. Different companies can be found across the spectrum, including mining production, consulting and engineering (mining and minerals), and equipment supply. A large number of green and brown fields projects are identified for the near future, and these will require a certain level of project management maturity to ensure success.

Similarly, the engineering industry - in particular, the energy and infrastructure sectors - is experiencing significant growth. Apart from the current Gautrain and 2010 Soccer World Cup stadium projects that are underway, a number of new development and upgrade projects can be identified. In the energy sector the South African government has announced its required capacity, with ESKOM planning to supply $70 \%$ and independent power producers the rest. This amounts to ESKOM rolling out more than R100 billion worth of capital expenditure over the next five years.

\section{$1.2 \quad$ Models for testing}

It is inevitable that many of the projects identified as part of the growth in South Africa will include the development of new products - whether a Generation IV nuclear reactor or a new remote-controlled underground mining system. Part of this new product development is the testing of models; and this plays a major role in the system engineering process, and specifically addresses the issue of quality.

One of the activities in the system engineering process is called 'System test and evaluation'. In addressing the subject of evaluation, the objective is to acquire a high degree of confidence, as early in the life cycle as possible, that the system will ultimately perform as intended [2].

Depending on the type and complexity of the system that is being developed, it is possible that the development of a pilot plant will be investigated to perform a number of the required tests indicated under 'Type 1 and 2 testing'.

\subsection{Project management in the industry}

It is unfortunately true that only a small number of projects in the engineering and mining industry in South Africa is completed 'successfully'. A very familiar saying is heard in numerous projects: "There is never enough time or money to plan the project correctly, but there is always enough time and money to do it right afterwards."

This 'recipe for failure' can be attributed largely to the way in which the project is defined during the stages leading up to project execution - specifically, the feasibility analysis and bidding/tendering stages. There is often a huge amount of pressure on the contractors and suppliers to estimate and budget for services and works as a result of deadlines that the client knew about but did not manage proactively. This pressure results in poor estimates and proposals being submitted, and thus a number of the identified risks materialising. 
Even though world class principles and guidelines for project management, and the associated tools and techniques, are well-known and preached within the industry, their actual implementation is often quite the opposite.

\subsection{Project management maturity}

One specific way in which an organisation can benchmark in order to improve its project success rate is to use a project management maturity model (or models) first, to evaluate the current level of maturity within the organisation, and second, to plan and focus on areas of improvement. This process can become an integral part of an organisation's way of 'doing business' that can ultimately lead to greater project success and bigger market share.

\section{$1.5 \quad$ Literature review}

The literature review focused on four specific areas to determine whether there is a link between pilot plant development and project management maturity.

\subsubsection{Project success}

Flyvbjerg, Bruzelius and Rothengatter [10] take a very open and honest look at the phenomenon of international mega-projects, and specifically infrastructure projects. The research shows that the formula for the approval of a multi-billion dollar project includes under-estimated costs, over-estimated revenues, under-valued environmental impacts, and over-valued economic development effects.

Lim and Zain Mohamed [13] conducted an exploratory re-examination of the criteria for project success. One of the key issues addressed in this study is the difference in the definitions of 'criterion' and 'factor'. In his paper on project success criteria, Atkinson [1] refers to the 'iron triangle' of cost, time, and quality as merely being two best guesses and a phenomenon.

A number of studies have also been conducted to determine project success factors and their occurrence and influence over the project lifecycle. In one of these studies, Pinto and Prescott [20] conducted a field study to investigate the changes in the importance of project critical success factors across four stages in the project lifecycle.

\subsubsection{Project management maturity}

Pennypacker and Grant [18] indicate that maturity models are designed to provide the framework that an organisation needs to develop its capabilities purposefully and progressively, in order to deliver projects successfully time after time. They state that project management maturity benchmarking is frequently used to manage improved project delivery by a single organisation over time. Benchmarking also provides an important means to compare project delivery capability between organisations, or between a specific organisation and industry norms.

Jugdev and Thomas [12] explain that in recent decades maturity models have emerged in the literature as concrete, tangible ways of assessing aspects of a firm's project management maturity. In 2004, Evrard and Nieto-Rodriguez [9] investigated whether a higher maturity level will go hand-in-hand with a higher performance level. The PriceWaterhouseCoopers maturity model [9] was used to assess the respondents.

Cooke-Davies and Arzymanow [5] investigated the nature and extent of variations between project management practices in six industries, in order to support a group of pharmaceutical R\&D organisations in their search for an optimum project management model. The investigation's results indicated different levels of maturity in different industries - specifically, higher maturity in petrochemical, defence, engineering, and 
similar industries than in industries such as pharmaceutical R\&D, construction, telecommunications, and financial services.

\subsubsection{Project management maturity models}

Pennypacker and Grant [18] highlight that many project management maturity models have emerged since the mid-1990s; an estimate in 2001 suggested that more than 30 models served the market [6].

One of these maturity models is the OPM3 (Organisational Project Management Maturity Model, 2003), a standard developed under the stewardship of the Project Management Institute (PMI).

Another maturity model developed by PM Solutions is the Project Management Maturity Model. In his book on the model, Crawford [7] highlights that the maturity concept is increasingly being used to map out logical ways to improve an organisation's service. The model uses the nine knowledge areas found in the PMl's A Guide to the Project Management Body of Knowledge (PMBOK ${ }^{\circledR}$ Guide) [21] as a point of reference for examining of project management capability.

\subsubsection{Pilot plants}

The internet encyclopaedia, Wikipedia, describes a pilot plant as a small chemical processing system that is operated to generate information about the behaviour of the system for use in the design of larger facilities. Pilot plants are used to reduce the risk associated with constructing large process plants.

Designers use a variety of models to ensure quality products (Nicholas \& Steyn, [17]). These include computer simulation models, mathematical models, three-dimensional scale models, and full-scale prototypes, all which give an impression of the final product, system, or subsystem. In the development of new products, constructing models such as prototypes plays an important role in minimising the risk of failing to meet technical requirements. Building different types of models normally coincides with project phases.

Even though a large quantity of available literature describes the use of pilot plants for generating tests results and input into further development of processes and systems, no applicable literature could be found regarding the link between project management maturity and the development of pilot plants.

From the literature review, it is concluded that a gap exists between the project management maturity models that are currently available, and their use to determine and improve the required level of maturity for the development of pilot plants.

\subsection{Objectives}

Given the above introduction and background to projects in the South African engineering and mining industry, it appears that the actual project management being conducted on a daily basis is far removed from the principles and guidelines that are available on the subject. One of the phenomena that points to this fact is the way in which projects are defined and awarded to contractors, and the way these projects are then managed and measured for success.

The fact that practices are far removed from the available principles and guidelines holds true for many international projects as well [10]. This indicates an underlying fundamental flaw in the initiation and planning stages of the project, and the way that the project's success is measured. This fundamental flaw creates and stimulates an environment where projects are approved and accepted with under-estimated costs, over-estimated revenues, and unrealistic time schedules. 
With the large amount of capital committed to projects in the industry, it is crucial that the project management maturity of South African mining and engineering organisations be in line with the requirements for successful project delivery, including projects involving the development of pilot plants.

The primary objectives of the research study were to determine the current level of project management maturity of South African companies involved in the development of pilot plants, and to determine what the required level should be to complete pilot plant projects successfully.

\section{THE SELECTED MATURITY MODEL}

The literature survey concluded that a large number of project management maturity models are currently being used in industry. One of these models was developed by Project Management Solutions [7]. Two of the model's characteristics make it ideal for use in the current study. The model is based on the nine knowledge areas of the PMBOK® Guide [21], which is well known and accepted within the South African mining and engineering industry. The indicated assessment method is not very cumbersome, and can easily be used to determine organisations' current level of maturity, as well as the required level of maturity.

\subsection{Model description}

The model has five distinct levels of maturity, and examines an organisation's implementation across the nine project management knowledge areas. The five maturity levels are patterned after the Software Engineering Capability Maturity Model (SE-CMM)[7]. Each of the levels represents a discrete organisational capability based on the summarylevel characteristics, as shown in Table 1.

\begin{tabular}{|l|l|}
\hline Level & Description \\
\hline 1 & Initial process \\
2 & Structure process and standards \\
3 & Organisational standards and institutionalised process \\
4 & Managed process \\
\hline 5 & Optimising process \\
\hline
\end{tabular}

Table 1: Maturity level description (Crawford [7])

\subsection{Suggested assessment method}

Crawford [7] supplies a self-assessment survey that can be used to determine the maturity level of an organisation. Review the description for each component in each of the nine knowledge areas (Chapters 2 - 11 of Crawford,[7]) and assess the organisation's level of maturity. Achievement of a given maturity level by an organisation is cumulative - that is, for each succeeding PMMM level, the assumption is that all criteria for the preceding levels for that component are being (or have been) fulfilled. For example, to assess yourself at Level 3 in Scope Definition, you must have in place all of the processes described in Levels 1,2 , and 3 of Scope Definition. After completing the assessment, determine the maturity level in each knowledge area. To do that, review the assessments of the knowledge area components, and select the lowest level of assessment: that is the maturity level in the specific area. To assess the overall Organisational Maturity Level, follow a similar method. Review the maturity assessment of each of the nine knowledge areas. Select the lowest level of assessment: that is the Organisational Maturity Level. 


\section{RESEARCH METHODOLOGY}

Given the fact that project management maturity models are fairly well-developed and available - as well as the fact that the required level of maturity for the development of pilot plants is not well-known in the industry - the research approach was based on a Delphi technique. This technique allows subject matter experts to give their opinions regarding the required level of maturity.

\subsection{Introduction to the Delphi technique}

The internet encyclopaedia, Wikipedia [24], describes the Delphi technique as a method for obtaining forecasts from a panel of independent experts over two or more rounds. After each round, an administrator provides an anonymous summary of the experts' forecasts and their reasons for them. When experts' forecasts have changed little between rounds, the process is stopped and the final round forecasts are combined by averaging.

The Delphi technique has been used by a large number of researchers, even though it has received both praise and critique. Recent research by Mason and Alamdari [15] includes a study to forecast the structure of air transport in the EU by 2015 in respect of network carriers, low cost airlines, and passenger behaviour. Griffith et al. [11] conducted a study to determine which literature-based definitions of low back pain (LBP) could be combined to produce sufficiently similar sets for use in a meta-analysis. Chu and Hwang [4] have used the Delphi approach in the diagnosis of severe acute respiratory syndrome (SARS) by using the input from multiple experts; and they have reported the superiority of this novel approach.

Mullen [16] indicates that the Delphi technique has been criticised over the years. Through critical examination of some of the controversies and misunderstandings that surround Delphi, Mullen [16]] aimed to dispel some of the myths and to demonstrate the wide scope and potential of this versatile approach. He noted that the labels describing the 'types' of Delphi have varied over the years, as well as the way that a Delphi 'study' is described.

\subsection{Delphi technique applied}

The Delphi technique, as described by Delbecq, Van de Ven and Gustafson [8] was used to design the research methodology.

\subsubsection{Stage 1 - Develop the Delphi questionnaire}

The following questions must be answered in order to achieve success from the research:

'Why are you interested in this study?'

Project performance in the South African mining and engineering industry is not very good. With the large number of new projects identified, the development of pilot plants will play a major role in the success of new products and systems. This study will assess the current level of maturity for organisations developing pilot plants, and determine the required level of maturity to develop pilot plants successfully.

\section{'What do you need to know that you don't know now?'}

The results from the research should indicate the current level of project management maturity of organisations developing pilot plants, as well as the required level of maturity to develop pilot plants successfully. 
'How will the results from the Delphi influence decision-making once the study is completed?'

The results from the Delphi study can be used as a benchmark for organisations in the industry, to optimise their current level of maturity.

The design of the questionnaire is based on the assessment template that was supplied with the PM Solutions maturity model. Due to the quantitative nature of the assessment, a decision was made to construct the questionnaire in a spreadsheet format to assist with post-processing the results.

\subsubsection{Stage 2 - Selection of respondents}

Due to the specific nature of the research topic, the respondents had to be carefully selected, ensuring that they had intimate knowledge of both pilot plants and the project management framework that is used as basis for the survey. The respondents were therefore selected based on past and present involvement in projects in the industry, and specific involvement in pilot plant projects and organisations dealing in the industry.

\subsubsection{Stage 3 - Selection of sample size}

From the literature it is evident that the required panel size varies for different types of studies. It was decided that a minimum of ten respondents should be selected for this study. The first survey was sent to all the respondents, while the second survey was sent only to those who completed the first survey.

\subsubsection{Stage 4 - First questionnaire}

The first survey was divided into three sections. The first section asked the respondents a number of general questions to assess their current position and background. The second section contained the PMMM survey, and instructed the respondents to complete the survey in the light of their organisations' current level of maturity. The third section was a repeat of the survey, instructing the respondents to indicate their opinion of the required maturity level to develop pilot plants successfully.

The objectives of the first round survey were to obtain the current level of project management maturity within the South African industry, and to obtain a first round opinion from the respondents about what they thought the level should be.

\subsubsection{Stage 5 - Analysis of first questionnaire}

The results from the first survey included an indication of the current maturity level of organisations in the industry, and the panel's opinion on the required level of maturity to develop pilot plants successfully.

\subsubsection{Stage 6 - Second questionnaire}

The second survey contained feedback from the first survey, pertaining to the respondents' opinion on the required level of maturity for successful pilot plant development. In the second survey, the respondents were asked to complete the same survey in the light of the first survey's results.

\section{RESULTS}

The first section below will discuss the distribution of the respondents who participated in the survey, as well as the response and attrition rates obtained. The second section will discuss the various maturity results that were obtained. 


\subsection{Respondent information}

The first round questionnaire was sent to a total of 16 experts in the field of pilot plant development. The experience of the experts and the different organisations that they are associated with gives a very good representation of the South African mining and engineering industry. The specific fields represented by the various experts included mineral processing, mining, petrochemical, nuclear, and mechanical.

The group of experts included both males and females aged between 20 and 50 . The positions occupied by the experts in their various organisations included senior manager, project manager, project engineer, process engineer, and divisional manager.

A response rate of $75 \%$ was achieved with the first survey, with 12 of the 16 experts returning the completed surveys. The second round survey was sent to the 12 respondents from the first round. Again a response rate of $75 \%$ was achieved, with 9 of the 12 experts responding. The attrition rate between round 1 and 2 is calculated to be $25 \%$. These numbers are acceptable, as 7 to 12 respondents are normally considered acceptable for a Delphi survey (Cavalli-Sforza \& Ortolano, [3]; Phillips, [19]; Linstone, [14]).

Five of the respondents indicated that they were familiar with the PMBOK Guide [21], with experience ranging from two to more than five years. Two of the respondents indicated that they were in possession of a project management certificate. The experience of the respondents in the industry - and specifically pilot plant projects - varied from small projects worth less than R500,000 to large projects in excess of R250 million.

\subsection{Maturity level assessment results}

The results from the maturity level assessment will be discussed in the same format that is used by Crawford [7].

\subsubsection{Project integration management}

The results for Project Integration Management indicate a definite difference between the current level of maturity and the required level for each of the components in the knowledge area. A maturity level of 4 is required for the components Project Plan Development, Project Plan Execution, and Change Control, with the corresponding current maturity level situated at 3 . This indicates that, for these components, project management must be conducted at a level of Managed Process, as opposed to the current level of Organisational Standards and Institutionalised Process, to successfully complete pilot plant projects. The required maturity level for the components Project Information System and Project Office is 3 , while the current level is at 2 . In order to conduct successful pilot plant projects, these components must be improved from a level of Structured Process and Standards to a level of Organisational Standards and Institutionalised Process.

\subsubsection{Project scope management}

The results for Project Scope Management indicate a definite difference between the current level of maturity and the required level for the various components in the knowledge area. The current level of maturity for the all the components in the knowledge area is level 3 , while the required level is 4 . This indicates that, in order to manage pilot plant projects successfully, Project Scope Management must improve from a level of Organisational Standards and Institutionalised Process to a level of Managed Process.

\subsubsection{Project time management}

The results for Project Time Management indicate a definite difference between the current level of maturity and the required level for the various components in the 
knowledge area. The current level of maturity for the components Activity Definition, Activity Sequencing, Schedule Development, and Schedule Control is rated at 3, as opposed to the required maturity level of 4 . This illustrates that these components must be improved from a level of Organisational Standards and Institutionalised Process to a level of Managed Process to ensure the successful completion of pilot plant projects. The component of Schedule Integration is currently rated at a level 2, while the required level is 4 , indicating a substantial improvement required from Structured Process and Standards to Managed Process.

\subsubsection{Project cost management}

The results for Project Cost Management indicate a definite difference between the current level of maturity and the required level for the various components in the knowledge area. The maturity level for all the components in the current environment is rated at level 3, compared with the required maturity level of 4 . This indicates that the maturity level must be improved from Organisational Standards and Institutionalised Process to Managed Process in order to ensure successful pilot plant projects.

\subsubsection{Project quality management}

The results for Project Quality Management indicate a definite difference between the current level of maturity and the required level for the various components in the knowledge area. The current maturity level for all of the components is rated at level 3 with the required level of maturity at level 4 . The results indicate that an improvement from Organisational Standards and Institutionalised Process to Managed Process is required for all the components to ensure successful pilot plant projects.

\subsubsection{Project Human Resource Management}

The results for Project Human Resource Management indicate a definite difference between the current level of maturity and the required level for the various components in the knowledge area. The current maturity level for component Organisation Planning is rated at level 2, while the required level is 3 . From the results it can be deduced that an improvement from Structured Process and Standards to Organisational Standards and Institutionalised Process is required to ensure successful pilot plant projects. For the components Staff Acquisition, Team Development and Professional Development, there is a significant difference between the current maturity level of 2 and the required maturity level of 4. This indicates that a definite improvement from Structured Process and Standards to Managed Process will be required ensuring pilot plant project success.

\subsubsection{Project communications management}

The results for Project Communications Management indicate a definite difference between the current level of maturity and the required level for the various components in the knowledge area. The current maturity level for the components Planning and Performance Reporting is rated at level 2 , while the required level is rated at level 3 . This indicates that an improvement is required from Structured Process and Standards to Organisational Standards and Institutionalised Process to ensure pilot plant project success. A significant difference exists between the current maturity level of 2 and the required maturity level of 4 for the components Information Distribution and Issues Tracking and Management. It can therefore be deduced from the results that an improvement from Structured Process and Standards to Managed Process will have significant impact on pilot plant project success.

\subsubsection{Project risk management}

The results for Project Risk Management indicate a definite difference between the current level of maturity and the required level for the various components in the knowledge area. A significant difference exists for all of the components between the current level of 
maturity (rated at level 2) and the required level of maturity (level 4). This indicates that an improvement from Structured Process and Standards to Managed Process will result in a definite increase in the success of pilot plant projects.

\subsubsection{Project procurement management}

The results for Project Procurement Management indicate that on knowledge area level the current level and required level of maturity are rated equally. However, there are differences between the current level of maturity and the required level for the various components in the knowledge area. The maturity level for component Procurement Planning is rated equally for the current and required levels. It can therefore be deduced that no improvement is required in this area to conduct pilot plant projects successfully. There are differences between the current level and the required level of maturity for the components Requisition, Solicitation / Source Selection, and Contract Management / Closure: the current level is rated at level 3, while the required level is level 4 . This indicates that improvements have to take place from Organisational Standards and Institutionalised Process to Managed Process to ensure successful completion of pilot plant projects.

\subsubsection{Summary and organisational maturity}

The results for the maturity levels of the knowledge areas and for organisational maturity are illustrated in Figure 1. The survey results indicate a difference in value between the current level of maturity and the required level of maturity for all the knowledge areas except Project Procurement Management. A difference also exists between the current and required organisational maturity level.

A number of specific interpretations can be made. None of the nine knowledge areas, nor any of their components, was rated at a maturity level of 5 . Only one component (Procurement Planning) of the 49 that make up the nine knowledge areas is currently rated equal to the required maturity level, while only one knowledge area, Project Procurement Management, rated equal to the required maturity level. The knowledge areas of Project Time Management and Project Risk Management displayed the largest difference between the current maturity level and the required maturity level ( 2 versus 4 ).

There is a difference between the current organisational maturity level (rated at 2 ) and the required organisational maturity level (rated at 3). This indicates that the management of certain key components of the various knowledge areas, as discussed above, needs to be improved to ensure that the organisational maturity level is improved, leading to successful pilot plant projects.

\section{SUMMARY OF RESULTS}

The research study assesses the project management maturity for the development of pilot plants within the South African mining and engineering industry. Five specific research questions were asked, based on the results in the previous chapter; these questions are addressed below.

The question regarding the current level of project management maturity in South African companies was directly answered by the results of the project management maturity survey that was completed by the panel of experts via a Delphi study. The results indicated the maturity level for 49 components contained within the nine knowledge areas of the PMBOK ${ }^{\circledR}$ Guide [21] as well as the maturity level for the knowledge areas. Finally, the organisational maturity level was also determined. 


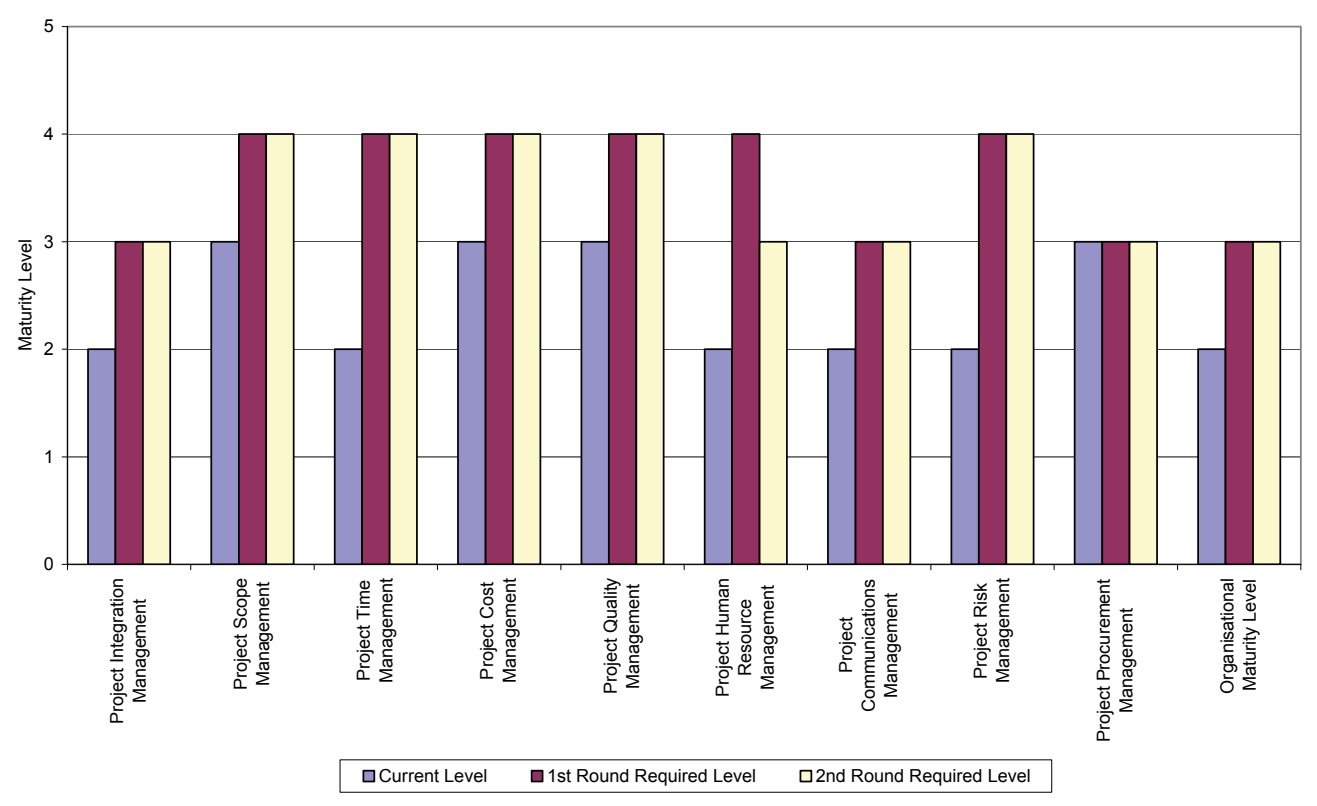

Figure 1: Maturity level for nine knowledge areas and organisational maturity level

The results from the study have a very high confidence level, as the distribution of experts participating in the study was representative of the mining and engineering industry in South Africa.

The question regarding the required level of maturity is closely linked to the previous question, and the conclusions made above are also valid for this question. The same process and panel of experts were involved in determining the required level of maturity for the development of pilot plants. The data obtained regarding the required maturity level is valuable for benchmarking and setting improvement targets for various organisations in the industry.

The maturity model developed by PMSolutions was selected for this study because it is based on the nine knowledge areas of the $P M B O K \otimes$ Guide [21], which is well known and accepted within the South African mining and engineering industry. Also, the assessment method is not very cumbersome and can easily be used to determine organisations' current level of maturity, as well as the required level of maturity.

The results from the Delphi study were obtained quite easily, and no questions or comments were received regarding the applicability of the model or the assessment questions to the specific projects. In fact, the simplicity of the project management maturity model is a friendly reminder not to over-complicate the approach to project management in specific industries. It can therefore be concluded that the maturity model by PMSolutions addresses most of the needs of pilot plant projects.

The development of pilot plants varies significantly in size (physical and value), and therefore they cannot necessarily be approached in the same way as conventional projects in the industry. One aspect that is certainly not addressed in the model used here is the factor of pilot plant size and the quantity of risk mitigation that will be achieved via the pilot plant. These factors will definitely have an influence on the project management approach, and therefore on maturity.

A significant difference was observed between the current level of maturity and the required level of maturity in all but one of the nine knowledge areas defined by the Project 
Management Institute. The two knowledge areas of Project Time and Risk Management showed significant differences between current and required maturity levels, and thus were identified as key areas for improvement.

\section{REFERENCES}

[1] Atkinson, R. 1999. Project management: Cost, time and quality, two best guesses and a phenomenon, it's time to accept other success criteria, International Journal of Project Management, 17(6), 337-342.

[2] Blanchard, B.S. 2003. System engineering management, $3^{\text {rd }}$ edition. John Wiley \& Sons, Inc., Hoboken, New Jersey.

[3] Cavalli-Sforza, V. and Ortolano, L. 1984. Delphi forecasts of land-use Transportation interactions, Journal of Transportation Engineering,110(3), 324-39, from MULLEN, P., 2003, Delphi: Myths and reality, Journal of Health Organisation and Management, 17(1), 37-52.

[4] Chu, H. and Hwang, G. 2007. A Delphi-based approach to developing expert systems with the cooperation of multiple experts, Expert systems with applications (in press).

[5] Cooke-Davies, T.J. and Arzymanow, A. 2003. The maturity of project management in different industries: An investigation into variations between project management models, International Journal of Project Management, 21, 471-478.

[6] Cooke-Davies, T.J., Schlichter, J. \& Bredillet, C. 2001. Beyond the PMBOK® Guide, Proceedings of the 32nd Annual Project Management Institute, 2001 Seminars \& Symposium.

[7] Crawford, J.K. 2002. Project management maturity model: Providing a proven path to project management excellence. Project Management Solutions, Inc. Havertown, Pennsylvania USA.

[8] Delbecq, A.L., Van de Ven, A.H. and Gustafson, D.H. 1975. Group techniques for program planning: A guide to nominal group and Delphi processes. Scott, Foresman and Co., Glenville.

[9] Evrard, D. and Nieto-Rodriguez, A. 2004. Boosting business performance through programme and project management. PriceWaterhouseCoopers.

[10] Flyvbjerg, B., Bruzelius, N. and Rothengatter, W. 2003. Megaprojects and risk - An anatomy of ambition. Cambridge University Press.

[11] Griffith, L.E., Hogg-Johnson, S., Cole, D.C., Krause, N., Hayden, J., Burdorf, A., Leclerc, A., Coggon, D., Bongers, P., Walter, S.D. and Shannon, H.S. 2007. Lowback pain definitions in occupational studies were categorized for a meta-analysis using Delphi consensus methods, Journal of Clinical Epidemiology, 60, 625-633.

[12] Jugdev, K. and Thomas, J. 2002. Project management maturity models: The silver bullets of competitive advantage, Project Management Journal, 33(4), 4-14.

[13] Lim, C.S. and Zain Mohamed, M. 1999. Criteria of project success: An exploratory re-examination, International Journal of Project Management, 17(4), 243-248.

[14] Linstone, H.A. 1978, The Delphi technique, in Fowles, R.B., (ed.), Handbook of futures research, Greenwood, Westport, CT, 271-300. 
[15] Mason, K.J. and Alamdari, F. 2007. EU network carriers, low cost carriers and consumer behaviour: A Delphi study of future trends, Journal of Air Transport Management (in press).

[16] Mullen, P.M. 2003. Delphi: Myths and reality, Journal of Health Organization and Management, 17(1), 37-52.

[17] Nicholas, J. M. and Steyn, H. 2008. Project management for business and technology, Butterworth-Heinemann, London (in press).

[18] Pennypacker, J.S. and Grant, K.P. 2003. Project management maturity: An industry benchmark, Project Management Journal, 34(1), 4-11.

[19] Phillips, R. 2000. New applications for the Delphi technique, Annual 'San Diego' Pfeiffer and Company, 2, 191-196, from Mullen, P., 2003, Delphi: Myths and reality, Journal of Health Organisation and Management, 17(1), 37-52.

[20] Pinto, J.K. and Prescott, J.E. 1988. Variations in critical success factors over the stages in the project lifecycle, Journal of Management, 14(1), 5-18.

[21] Project Management Institute, Inc. 2004. A Guide to the Project Management Body of Knowledge (PMBOK ${ }^{\circledR}$ Guide). Newtown Square, Pennsylvania USA.

[22] Project Management Institute, Inc. 2003. Organisational Project Management Maturity Model (OPM3). Newtown Square, Pennsylvania USA.

[23] Wikipedia, http://en.wikipedia.org/wiki/Pilot_plant, accessed $18^{\text {th }}$ June 2007.

[24] Wikipedia, http://en.wikipedia.org/wiki/Delphi_method, accessed $9^{\text {th }}$ May 2007. 
http://sajie.journals.ac.za 